\title{
DISTRIBUIÇÃO ESPACIAL E CARACTERIZAÇÃO GEOLÓGICA DOS ARENITOS ASFÁLTICOS DA BORDA LESTE DA BACIA DO PARANÁ NO ESTADO DE SÃO PAULO
}

\author{
CARLOS CÉSAR DE ARAÚJO ${ }^{1}$, JORGE KAZUO YAMAMOTO $^{1}$ \& SIDNEI PIRES ROSTIROLLA $^{2}$
}

\begin{abstract}
SPATIAL DISTRIBUTION AND GEOLOGICAL CHARACTERIZATION OF TAR SANDSTONES OF THE ESTERN PARANA BASIN BORDER IN THE STATE OF SÃO PAULO This paper focuses on the spatial distribution of the main tar sand occurrences in the Eastern Border of the Paraná Basin, São Paulo State. The spatial analysis of these occurrences was performed according to geological features present in the area. Field data, geocronological data, airborne magnetometrics and remote sensing data have provided information for structural maps, lineament maps and magnetometric maps. Based on the regional and field data it was described the main elements and processes related to the genesis of the tar sand occurrences in the area. It was concluded that the best genetic model relates oil generation to the intrusion of sills of the Serra Geral Formation in the black shales of the Irati Formation; migration through faults and dike walls and accumulation in the sandstones of Pirambóia Formation. trapped by argillaceous layers of the interdune and fluvial facies of Pirambóia Formation and by basic dikes.
\end{abstract}

Keywords: Tar sand, Paraná Basin, Airborne Geophysics, Remote Sensing, GIS.

\begin{abstract}
Resumo Este trabalho apresenta a distribuição espacial das principais ocorrências de arenitos asfálticos na Borda Leste da Bacia do Paraná em São Paulo. Analisa-se a distribuição espacial destas ocorrências segundo os elementos geológicos presentes na área. Foram utilizados dados de campo, dados geocronológicos, aeromagnetométricos e imagens de sensoriamento remoto. Com estes dados foram gerados mapas de contorno estrutural de camadas, mapas de lineamentos e mapas magnetométricos. Baseado na análise dos dados regionais e dados de campo foram descritos os principais elementos e processos relacionados à ocorrência de arenitos asfálticos na área. Conclui-se que o melhor modelo genético relaciona a geração do óleo à intrusão de soleiras da Formação Serra Geral nos folhelhos negros da Formação Irati; migração ao longo de falhas e das paredes de diques e acumulação nos arenitos da Formação Pirambóia aprisionada verticalmente por camadas argilosas da fácies de interduna e fluvial da Formação Pirambóia e por diques básicos.
\end{abstract}

Palavras-chave: Arenito asfáltico, Bacia do Paraná, Aerogeofísica, Sensoriamento Remoto, SIG.

INTRODUÇÃO A borda leste da Bacia do Paraná no estado de São Paulo apresenta mais de uma dezena de afloramentos de arenitos asfálticos ou betuminosos. Estas ocorrências são compostas por arenitos da Formação Pirambóia, principalmente de granulometria média e de boa permeabilidade e porosidade, os quais foram preenchidos secundariamente por material betuminoso. Apenas uma das ocorrências situa-se em arenitos da Formação Tatuí. Estes afloramentos não contêm óleo no estado líquido.

As ocorrências de arenitos asfálticos no Estado de São Paulo foram alvo de intenso estudo até 1950. Após a primeira guerra mundial houve a percepção no país da necessidade de se procurar reservas de hidrocarbonetos. Nesta época foram instaladas duas minerações de arenito asfáltico para destilação de petróleo. Na segunda metade do século, a Petrobrás pesquisou a região visando acumulações de óleo e gás em trapas estruturais. A Paulipetro pesquisou a Bacia do Paraná no fïm da década de 70, início dos anos 80 .

Este trabalho apresenta a distribuição espacial das ocorrências de arenitos asfálticos no estado de São Paulo e discute os aspectos descritivos destas ocorrências. O objetivo principal do estudo foi a proposição de modelos genéticos, com base na relação espacial das ocorrências e interpretações de dados aeromagnetométricos, de sensoriamento remoto e dados de campo, além de datações geocronológicas. A gênese das ocorrências de arenito asfáltico está relacionada aos sistema petrolífero Irati-
Pirambóia (Araújo et al. 2000), no qual o efeito termal das intrusões Serra Geral nos folhelhos negros Irati (Simoneit et al. 1978a, Simoneit et al., 1978b, Araújo et al., 2000) teve papel importante na formação das ocorrências.

TRABALHOS ANTERIORES A presença de arenitos asfálticos na borda leste da Bacia do Paraná é conhecida desde o século 19. O primeiro estudo foi apresentado pelo belga Auguste Collon em 1897 numa área no Morro do Bofete (Rodovia Castelo Branco, km 173,5 sentido capital-interior). Collon (1897) atribui o betume do arenito a proveniência de um reservatório de petróleo fraturado situado em profundidade. Segundo Oliveira (1920), estas ocorrências acham-se sempre nas proximidades de diques de rochas eruptivas. Para Washburne (1930), o arenito Botucatu, que inclui as formações Botucatu e Pirambóia, está situado na melhor posição para acumular o óleo originado do folhelho Irati. O autor faz. referência a uma camada de arenito formando paredões ao sul do Rio Tietê na Fazenda Saltinho, próximo a Porto Martins. Oliveira (1940) também cita diversos afloramentos de arenitos asfálticos em São Paulo e os interpreta como um "lençol" de petróleo, dos quais a erosão carregou os sedimentos sobrepostos. O relatório do Conselho Nacional do Petróleo (CNP 1944) observa a disposição de arenitos betuminosos entre Guareí e as margens do rio Tietê, alinhados na direção sul-norte. Para os autores do relatório este "alinhamento" faz supor que os depósitos são "jazidas fós-

I. Instituto de Geciências, Universidade de São Paulo, Rua do Lago, 562, Cidade Universitária, São Paulo, SP, CEP 05508-900, ccaraujo@usp.br / jkyamamo@usp.br

2 - Departamento de Geologia, Universidade Federal do Paraná, Centro Politécnico, Curitiba, PR, CEP 81531-990, rostirolla@geologia.ufpr.br 
seis" de óleo expostas pela erosão. Segundo Andrade \& Soares (1971), o óleo das ocorrências foi gerado na Formação Irati. Franzinelli (1972) observa que os arenitos asfálticos têm ocorrência em flancos de altos estruturais e a migração ocorreu por capilaridade e/ou devido à pressão gerada pelas intrusivas básicas; além disso, falhas e fraturas teriam facilitado a migração do óleo. Thomaz Filho (1982) analisa os dados de 26 sondagens, testemunhadas e perfiladas realizadas pela Petrobrás na ocorrência Betumita (Fig. 1). Segundo o autor, as impregnações têm teores que variam desde indícios até cerca de $17 \%$ de óleo em peso, com média de $5,5 \%$. A área de ocorrência do óleo atinge aproximadamente $0,4 \mathrm{~km}^{2} \mathrm{e}$ a espessura de arenito impregnado chega a mais de $80 \mathrm{~m}$. Fúlfaro et al. (1997) apresentam um resumo descritivo dos condicionantes geológicos das ocorrências de arenitos asfálticos.

GEOLOGIA DA ÁREA DE ESTUDO Na área de estudo (Fig. 1A) afloram as rochas do Subgrupo Irati e da Formação Teresina, Permiano e Grupo São Bento, Triássico-Jurássico, constituído pelas Formações Pirambóia, Botucatu e Serra Geral. Na base da sequieencia aflorante, estão as rochas do Subgrupo Irati compostas por sequiências de folhelhos e calcários. Em seguida encontramse os litotipos da Formação Teresina, compostos basicamente por siltitos arroxeados intensamente fraturados. No topo da Formação Teresina encontra-se a Camada Porangaba, proposta por Matos (1995), composta por brechas ora de matriz pelítica, ora de matriz arenosa com intraclastos.

Em contato ora abrupto, ora transicional com a camada Porangaba encontram-se os arenitos da Formação Pirambóia, constituídos por arenitos médios e finos em seqüências de estratificações cruzadas de grande porte (métricas). Por vezes verificam-se estratificações plano-paralelas nos arenitos da Formação Pirambóia próximos ao contato com a Camada Porangaba. Também foram observados litotipos compostos por siltitos e argilitos lenticulares intercalados nas sequiências de estratificações cruzadas, relacionados a depósitos de interdunas. A formação atinge espessuras de até $130 \mathrm{~m}$ em poços na região de Anhembi. Briguetti (1994) identificou quatro grupos de fácies na Formação Pirambóia na Bacia do Paraná: dunas, interdunas, lençóis de areia e fluviais. Caetano-Chang (1997), baseada em dados de perfis de poços na região de Anhembi, interpreta que há diminuição da presença de água influenciando a sedimentação.

A Formação Botucatu contém arenitos médios avermelhados com grãos foscos bem arredondados. Esta litologia, na área de estudo, tem um aspecto monótono com estratificações cruzadas de grande porte tangenciais na base. Afloram rochas básicas da Formação Serra Geral na forma de derrames tabulares sobrepostos à Formação Botucatu e também na forma de soleiras na Formação Pirambóia e no contato entre as formações Teresina e Pirambóia, além de numerosos diques dispersos por toda a região.

Fúlfaro et al. (1982) interpretam, durante a transição permotriássica, uma mudança do nível de base regional. Neste período, um mar raso (Formação Teresina) é ocupado por dunas litorâneas (Formação Pirambóia) e posteriormente por dunas de um deserto continental (Formação Botucatu). Para aqueles autores, esta mudança ocorreu em princípio devido ao levantamento dos Andes Meridionais e à movimentação tectônica positiva do assoalho da Bacia do Paraná.

Em toda a Bacia do Paraná, segundo Zalán (1991), dois estilos estruturais principais estão presentes: deformações associadas a intrusões ígneas e deformações associadas a reativações com elementos tectônicos lineares de direção NE e NW. Do mesmo modo, na área de estudo é notável a presença de estruturas lineares de direções NW e NE (Fig. IB e Fig. 4A). Estas estruturas consistem de falhas, diques de rochas básicas, alinhamentos aeromagnéticos e de relevo. Considera-se que o padrão NW esteja ligado ao Arco de Ponta Grossa, principalmente às reativações ao longo do alinhamento Guapiara, ou seja, ao tectonismo derivado da Ativação Juro-Cretácea (Reativação Wealdeniana de Almeida 1967; Ativação Mesozóica de Almeida 1972; Evento SulAtlântico de Schobbenhaus et al. 1984; Reativação Pós-Paleozóica de Almeida \& Carneiro 1989). O padrão NE também sofreu influência dos fenômenos citados anteriormente, mas considera-se sua origem principal nas zonas de fraqueza do embasamento.

As principais estruturas da área de afloramento das ocorrências são os altos estruturais de Anhembi e Carlota Prenz, além do sistema de falhas Torre de Pedra e Morro do Bofete. Estas estruturas caracterizam-se pelo afloramento de rochas da Formação Teresina (Permiano) contornadas por rochas da Formação Pirambóia (Triássico). Mais de $90 \%$ das ocorrências estudadas estão espacialmente próximas destas estruturas.

Riccomini (1995) descreve diques clásticos presentes em sedimentos da Formação Teresina como evidências diretas do tectonismo sin-sedimentar no Permiano Superior da Bacia do Paraná.

Junto à represa de Barra Bonita, às margens do rio Tietê, cercanias da cidade de Anhembi, aflora o alto estrutural Anhembi (Fig. 1A). As cotas variam de 450 a $600 \mathrm{~m}$ e os contatos entre a Formação Pirambóia e Teresina variam de 460 até 545 m, de acordo com levantamentos de campo. A estrutura de Anhembi caracteriza-se por um eixo maior de direção N50W e falhas de direção N, NW e NE. A região noroeste da cidade de Anhembi é caracterizada por uma expressiva anomalia de drenagem na forma de semi-circunferência formada pelo rio Alambari e por um braço da represa de Barra Bonita, nesta anomalia de drenagem também são observadas drenagens radiais como o ribeirão Agua do Monjolo e córrego Barreirinho(Fig. 2).

O alto estrutural de Carlota Prenz (Still 1952, apud Soares 1971) aflora na porção sul da área de estudo, ao norte da cidade de Angatuba (Fig. 1A). Este alto ocorre dentro de uma estrutura anelar, aqui denominada estrutura do Jacu, caracterizada pela anomalia de drenagem formada pelos rios Santo Inácio e Capivari (Fig. 3). $\mathrm{O}$ alto de Carlota Prenz está junto às drenagens radiais concêntricas, na porção sul da estrutura do Jacu, formadas pelo ribeirão Antônio José e ribeirão da Restinga. Os siltitos Teresina afloram em dois corpos quilométricos de forma elíptica cujo eixo maior tem direção aproximada N-S.

O sistema de falhas Torre de Pedra tem direções que variam de N30E a N40W, e localiza-se no limite leste da estrutura anelar (Fig. 3). Segundo Soares (1973) e Franzinelli (1972), uma falha normal deste sistema aflora na Rodovia Castelo Branco, km 173,5, próximo à ocorrência de arenito asfáltico do Morro do Bofete. O sistema Guareí tem direção N40E e localiza-se na porção SE da estrutura anelar e o sistema Morro do Bofete de direção N50W está no limite N-NE da estrutura.

Aeromagnetometria, Sensoriamento Remoto, Contorno Estrutural Os dados magnetométricos utilizados fazem parte do projeto Botucatu com direção de vôo N-S e espaçamento de 2 km. As linhas de vôo foram interpoladas utilizando um interpolador de mínima curvatura gerando uma imagem de campo total. Desta imagem base, com filtro co-seno direcional para eliminar feições NS decorrentes de problemas de nivelamento, foram obtidas imagens 


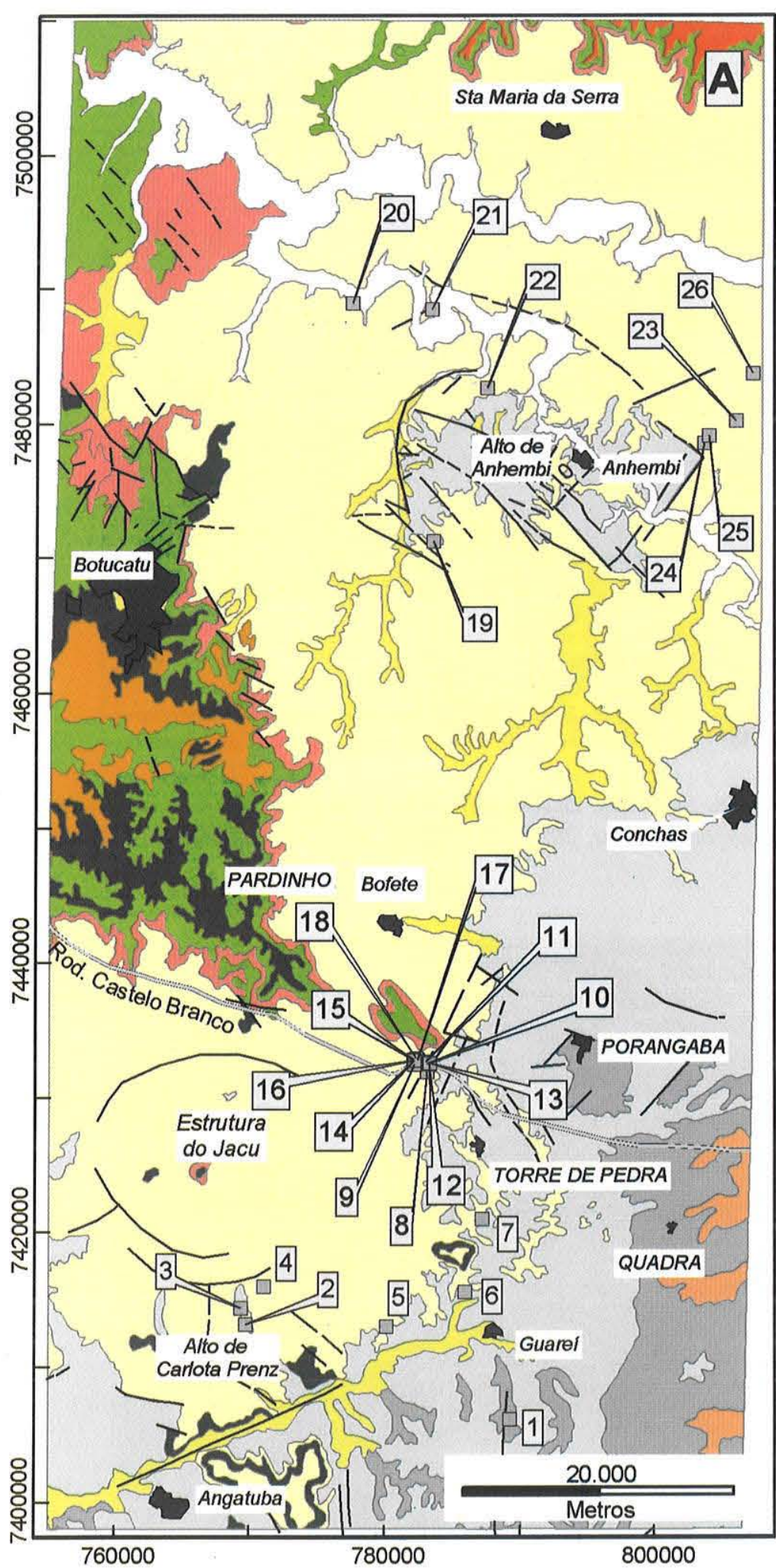

Quaternário-Terciário

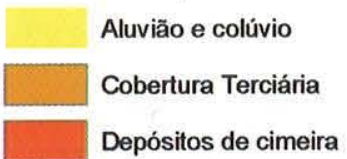

\section{Cretáceo}
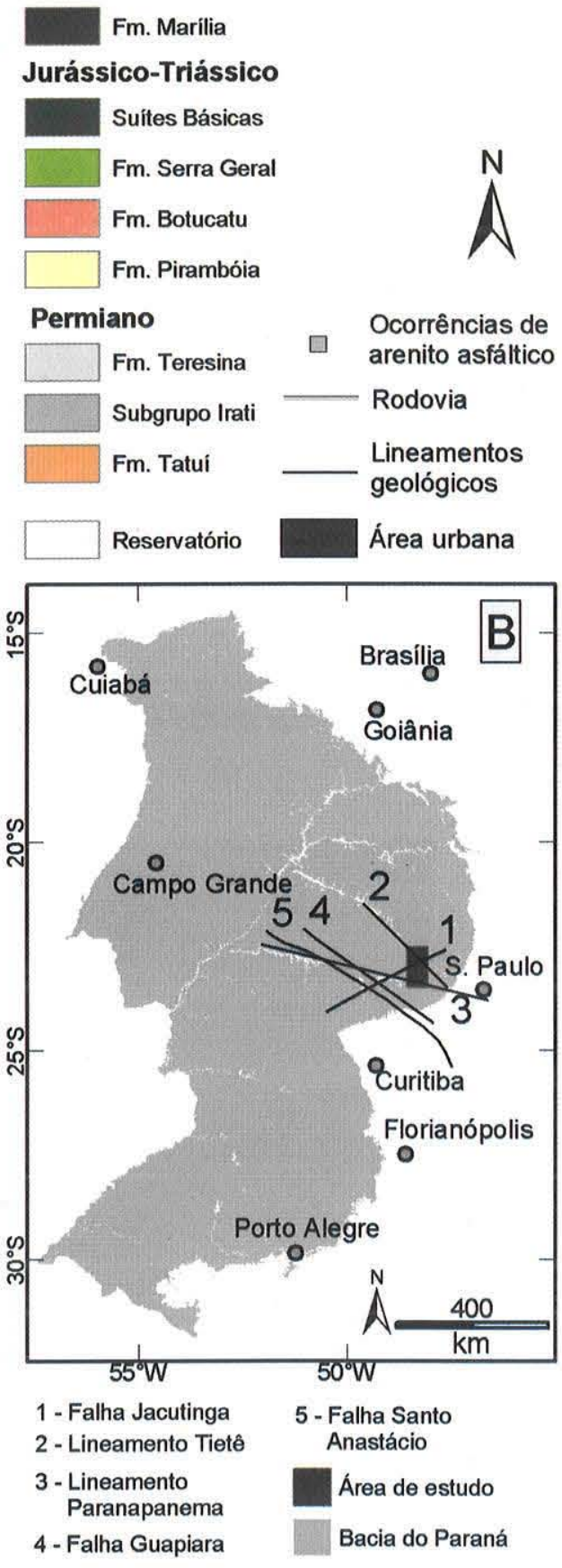

Figura I - (A) Ocorrências de arenito asfáltico e geologia da área de estudo (modificado de DAEE-UNESP 1984). (1) Jacutinga; (2)Sobar; (3)Sobar II; (4)Sobar III; (5)Itatigue; (6)Nhaíva; (7)Bairro Quebra; (8)Fazenda São Jorge; (9)Fazenda São Jorge II; (10)Morro do Bofete; (11)Morro do Bofete II; (12)Morro do Bofete III; (13)Morro do Bofete IV; (14)Bairro da Mina; (15)Bairro da Mina II; (16)Bairro da Mina III; (17)Estrada da Mina; (18)Estrada da Mina II; (19)Piapara; (20)Porto Martins; (21)Volta Grande; (22)Braço da Represa; (23)Betumita; (24)Moquém; (25)Moquém II; (26)Fazenda Ribeirão Claro. (B) Principais estruturas da Bacia do Paraná próximas da área de estudo (modificado de Zalán 1991, CPRM 2001a e b) 


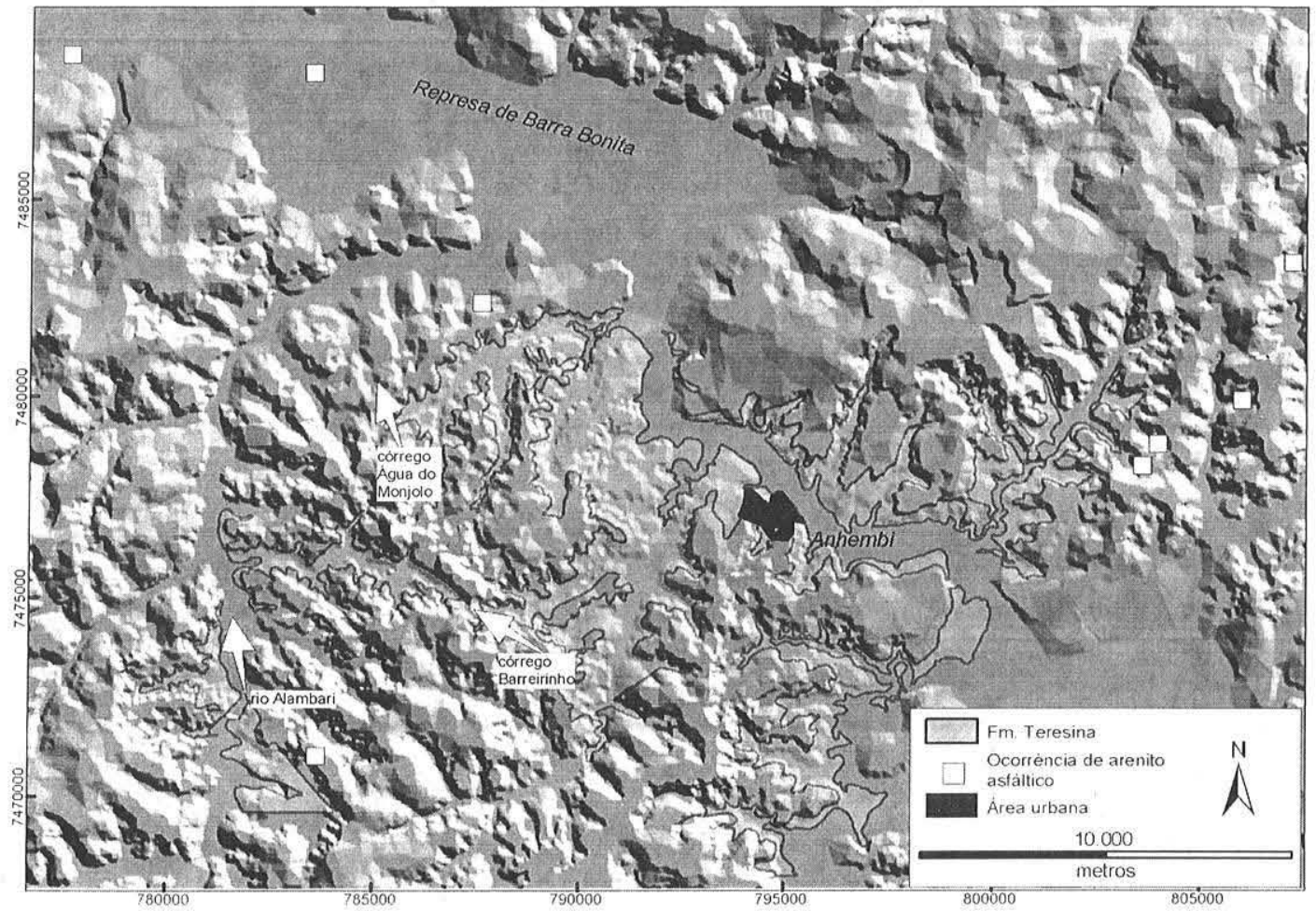

Figura 2 - Modelo numérico de terreno da área do Alto Estrutural de Anhembi onde se observa a anomalia de drenagem em forma de sem-circunferência do Rio Alambari, iluminação do norte, $30^{\circ}$, os quadrados indicam as ocorrências da área.

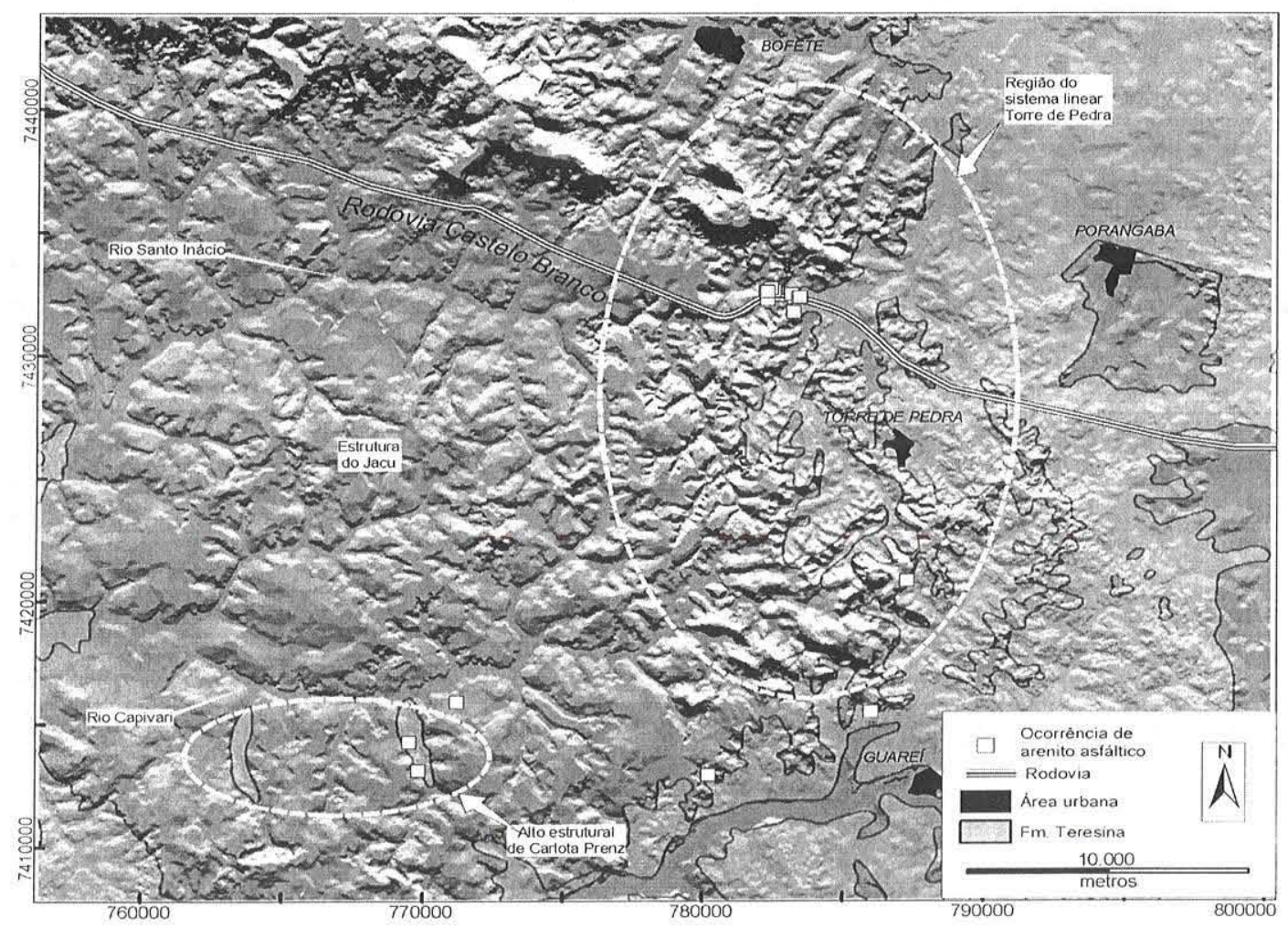

Figura 3 - Modelo numérico de terreno da área da Estrutura do Jacu onde se observa a anomalia de drenagem anelar. iluminação do norte, $30^{\circ}$. Os quadrados indicam as ocorrências da área. 
de redução ao pólo, sinal analítico (Fig. 4B) e fase do sinal analíti$\mathrm{co}, \mathrm{I}^{\mathrm{a}}$ derivada vertical e controle automático de ganho. Para a interpretação, foram utilizadas principalmente as imagens de sinal analítico e campo total. Também foi considerada, de modo auxiliar,

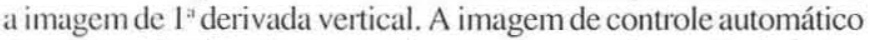
de ganho foi utilizada eventualmente para confirmação da interpretação de lineamentos pouco aparentes.

A interpretação considerou dois aspectos: lineamentos magnéticos e texturas das porções de altos magnéticos (Fig. 4A). Os lineamentos magnéticos foram interpretados como diques de rochas básicas e falhas. Os altos magnéticos foram considerados indicadores da presença de rochas básicas, sejam derrames ou intrusões. As áreas onde a textura apresenta uma alta frequêencia de altos magnéticos foram consideradas como dominadas por rochas extrusivas. A alta frequiência de altos magnéticos indica fontes superficiais. As áreas onde a frequiência é média a baixa foram consideradas como dominadas por rochas intrusivas aflorantes ou não. Conclui-se que os alinhamentos magnéticos NW e NE interpretados na área relacionam-se ao Arco de Ponta Grossa (Ativação Juro-Cretácea) e à estruturação do embasamento. Atestase a coincidência da interpretação com a realidade de campo. Por exemplo, na porção oeste da área de estudo, região de Botucatu (Fig. 4A). Foram interpretadas feições de alta frequiência de altos magnéticos, como observado na figura 4B, que estão relacionadas aos derrames Serra Geral observados no planalto de Botucatu.

A interpretação das feições lineares de relevo e de drenagem (Fig. 4A) foi feita com base na imagem de sensoriamento remoto Landsat 7 ETM+ de 29 de novembro de 1999 e na rede de drenagem digitalizada de oito cartas topográficas IBGE 1:50.000 (Fig. 4C). Com o auxílio de um Sistema de Informação Geográfica (SIG) foi feita a sobreposição dos dados de drenagem e imagens de satélite para conferir e complementar os dados de drenagem. A interpretação foi executada interativamente com a utilização de imagens RGB457, Principal Componente I e Banda 5 considerando as feições positivas (relevo) e negativas (drenagem).

Os lineamentos interpretados têm direções principais N50W e NI0-30E na área do Jacu e N45-70W e NI0-30E na área de Anhembi. Em campo, na área do Jacu observaram-se falhas oblíquas sinistrais N30-40E e falhas dextrais N30-70W. Nas porções central e sudeste da área de estudo há estruturas lineares EW dextrais principalmente na forma de fraturas escalonadas. Na área do Jacu também foram encontrados diques clásticos na Formação Teresina de direções NW e NE. Na área de Anhembi foram confirmadas falhas oblíquas sinistrais N50-60W quilométricas com características transtencionais inclusive com intrusões ígneas básicas ao longo da direção principal. Estruturas NE também foram confirmadas em

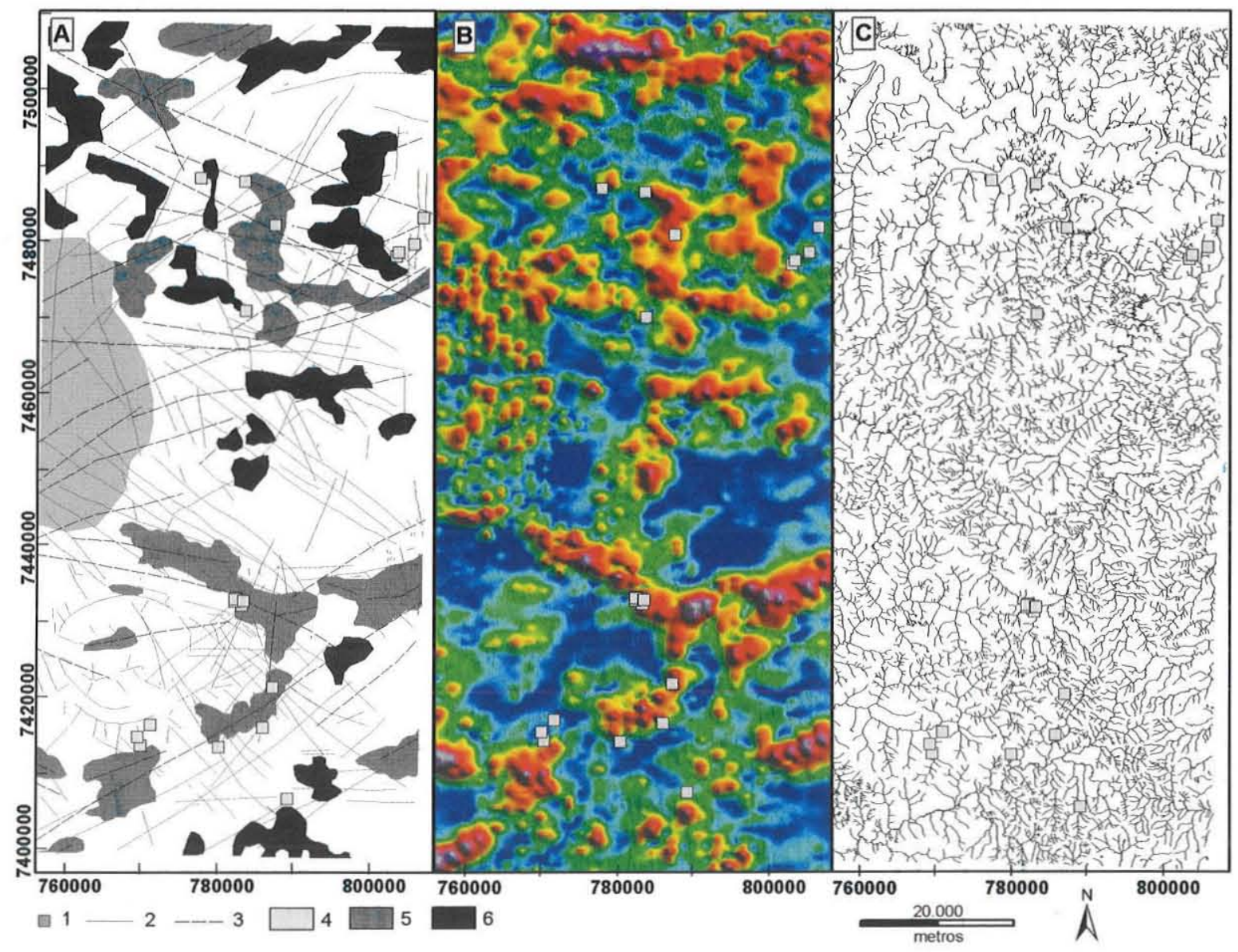

Figura 4 - (A) Interpretação geológica dos dados de sensoriamento remoto, rede de drenagem e aeromagnetometria: (1) Ocorrências de arenito asfáltico; (2) Lineamentos geológicos interpretados, feições positivas e negativas; (3) Lineamentos magnéticos; Padrão de textura nas áreas de alto magnetométrico - (4) Alta frequiência, derrames vulcânicos; (5) média freqüência, corpos não aflorantes rasos; (6) baixa frequiência, corpos não aflorantes profundos. (B) Mapa de sinal analítico do campo magnético com iluminação NE. (C) Rede de drenagem digitalizada, escala 1:50.000. 
duas falhas com direção N20E e N50E.

A geração de mapas de contorno estrutural envolveu o levantamento da posição espacial dos contatos entre a Formação Teresina e a Formação Pirambóia com trabalho de campo. Foram utilizados mapas topográficos na escala 1:10.000 do Instituto Geográfico e Cartográfico do Estado de São Paulo como base. Complementarmente, foram utilizados dados disponíveis no Relatório DEXPRO 40I (Petrobrás 1971, apud Franzinelli 1972).

Conclui-se com base nos lineamentos interpretados (Fig. 4A), em escala regional, que as ocorrências estão relacionadas a grandes lineamentos estruturais e magnéticos, além de altos estruturais. Além disso, todas as ocorrências estão posicionadas junto às bordas de altos magnéticos. Estes altos magnéticos caracterizam-se por média a baixa frequiências. Propõe-se que sejam decorrentes de corpos ígneos intrusivos básicos.

Uma das características das ocorrências de arenitos asfálticos é seu posicionamento estratigráfico na base da Formação Pirambóia, próxima da Formação Teresina. No mapa de contorno estrutural observam-se as ocorrências associadas principalmente a áreas de altos estruturais como os altos do Sobar, Areia Branca, Quebra, Morro do Bofete, Piapara e Anhembi (Fig. 5).

\section{OCORRÊNCIASDEARENITOSASFÁLTICOSNABACIADO}

PARANÁ Localização das ocorrências Foram encontradas 26 ocorrências de arenito asfáltico em mais de 15 localidades no Estado de São Paulo (Tabela 1). Entre estas foram descritas 3 novas ocorrências (Braço da Represa, Moquém e Sobar II/III). As ocorrências localizam-se próximas do rio Tietê (área do alto estrutural de Anhembi) região do município de Anhembi e à norte do rio Paranapanema (área da estrutura do Jacu) na região dos municípios de Angatuba, Guareí e Bofete. A área encontra-se situada na Depressão Periférica Paulista; de modo geral, a topografia é pouco acidentada, mas há áreas de escarpa com desníveis de até $300 \mathrm{~m}$, como na Serra de Botucatu. A rede de drenagem é estruturada e relacionada a condicionantes geológicos.

Aspecto geral - principais ocorrências As ocorrências são encontradas em áreas íngremes, cortes do terreno ou meia-encostas. A estrutura sedimentar mais comum é a estratificação cruzada de médio e grande porte. As amostras de mão são coesas devido a ação cimentante dos hidrocarbonetos com arenitos siliciclásticos de granulometria média a grossa, grãos de esfericidade moderada, subarredondados com contatos côncavo-convexos. A maturidade varia de submatura a matura. A distribuição do hidrocarboneto no arenito não é sempre homogênea devido às diferentes estruturas sedimentares dos arenitos que causam variações na permeabilidade e porosidade, o que proporciona diversos aspectos às amostras de mão, desde maciços até listrados e pintalgados. Em geral, apresentam estratos centimétricos e algumas vezes milimétricos. Notou-se nas amostras de mão a presença de pequenas fissuras abertas preenchidas por óleo (Fig. 6), com largura milimétrica e comprimento centimétrico.

Em lâmina delgada nota-se a ausência de hidrocarbonetos nas porções preenchidas por material argiloso. Em algumas lâminas nota-se a presença de porosidade não preenchida por betume, matriz ou cimento. Os contatos de grãos do arenito Pirambóia são frouxos, variando de côncavo-convexos até grãos flutuantes (Fig. 7A). Já os contatos de grãos do arenito Tatuí (ocorrência Jacutinga) são suturados e côncavo-convexos (Fig. 7B). Não se observou obstrução da porosidade por cimentação.

Conclui-se que o processo de compactação e diagênese esta-

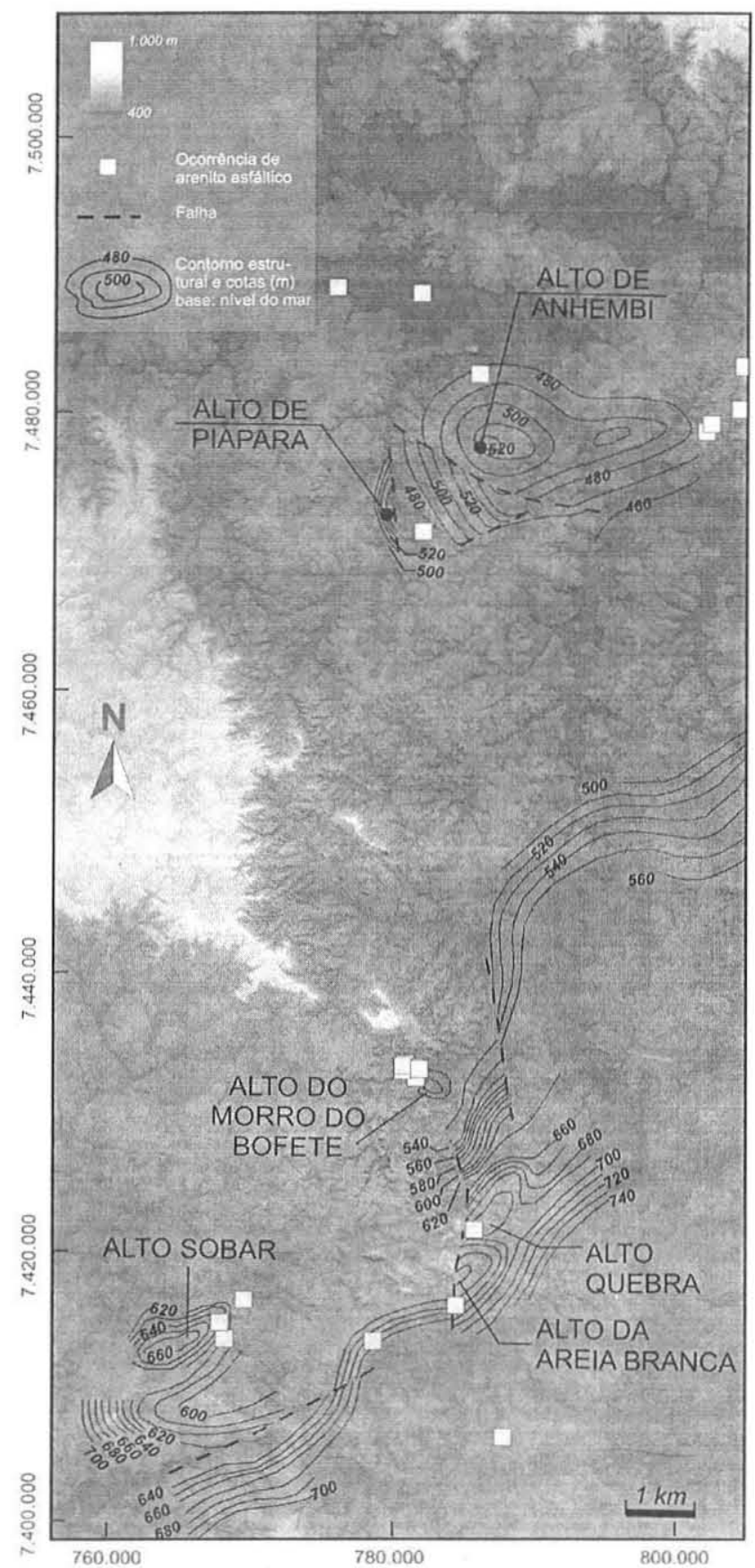

Figura 5 - Mapa de contorno estrutural do topo da Formação Teresina.

va mais adiantado no arenito Tatuí em relação ao arenito Pirambóia no tempo da chegada dos hidrocarbonetos na rocha reservatório. O arenito Tatuí já estava soterrado pelos sedimentos das Formações Teresina e Pirambóia. Esta é uma indicação que o óleo também chegou no arenito Permiano Tatuí após a deposição da Formação Pirambóia no Triássico. Já os contatos frouxos dos grãos do arenito Pirambóia indicam que, no tempo da chegada do óleo, o processo de compactação existia, mas não tinha a mesma intensidade como na Formação Tatuí. 
Tabela I - Localização das principais ocorrências da área de estudo

\begin{tabular}{|c|c|c|c|c|c|c|c|}
\hline Ocorrência & $\begin{array}{c}\text { UTM E } \\
(\mathrm{m})\end{array}$ & $\begin{array}{l}\text { UTM N } \\
(\mathrm{m})\end{array}$ & Cota & Dique associado & $\begin{array}{c}\text { Espessura } \\
(\mathrm{m})\end{array}$ & $\begin{array}{l}\text { Prof. Teresina } \\
(\mathrm{m})\end{array}$ & $\begin{array}{l}\text { Prof. max. } \\
\text { (m) }\end{array}$ \\
\hline zutinga' & 789316 & 740606 & 660 & Não & 5 & - & - \\
\hline tigue $^{2}$ & 780238 & 7412922 & 702 & Não & 31 & 48 & 38 \\
\hline laiva ${ }^{2}$ & 786034 & 7415501 & 703 & $\operatorname{Sim}(N E)$ & 93 & 70 & 57 \\
\hline bar & 769878 & 7413118 & 625 & Não & 9 & 35 & 28 \\
\hline bar $\mathrm{II}^{2}$ & 769534 & 7414274 & 645 & Não & - & - & - \\
\hline bar $\mathrm{III}^{2}$ & 771234 & 7415906 & 630 & Não & - & - & - \\
\hline inro Quebra ${ }^{2}$ & 787292 & 7420877 & 703 & Não & - & - & - \\
\hline zenda Sâo Jorge ${ }^{2}$ & 783226 & 7431789 & 569 & $\operatorname{Sim}(N E)$ & - & - & - \\
\hline zenda São Jorge II ${ }^{2}$ & 782302 & 7432310 & 536 & $\operatorname{Sim}(N E)$ & - & - & - \\
\hline orro do Bofele ${ }^{2}$ & 783254 & 74.32376 & 544 & $\operatorname{Sim}(N)$ & - & 57 & - \\
\hline orro do Bofete $\mathrm{II}^{2}$ & 783150 & 7432514 & 553 & $\operatorname{Sim}(N E)$ & - & - & - \\
\hline orro do Bolete $\mathrm{III}^{2}$ & 783412 & 7432378 & 553 & $\operatorname{Sim}(N)$ & - & - & - \\
\hline orro do Bofete IV ${ }^{2}$ & 783450 & $74324(02$ & 558 & $\operatorname{Sim}(N)$ & - & - & - \\
\hline irro da Mina $^{2}$ & 782274 & 7432619 & 543 & $\operatorname{Sim}(N E)$ & - & - & - \\
\hline irrro da Mina $\mathrm{II}^{2}$ & 782259 & 7432660 & 540 & Sim (NE) & - & - & - \\
\hline irro da Mina $\mathrm{III}^{2}$ & 782290 & 7432636 & 539 & Sim (NE) & - & - & - \\
\hline Irada da Mina ${ }^{2}$ & 782530 & 7432650 & 539 & $\operatorname{Sim}(N E)$ & - & - & - \\
\hline trada da Mina $\mathrm{II}^{2}$ & 782439 & 7432752 & 551 & $\operatorname{Sim}(\mathrm{NE})$ & - & - & - \\
\hline apara* ${ }^{2} 2$ & 783650 & 7471000 & 577 & Não & 16 & 80 & 20) \\
\hline oquém² ${ }^{2}$ & 803648 & 7478267 & 547 & $\operatorname{Sim}(\mathrm{NE})$ & - & - & - \\
\hline oquém II ${ }^{2}$ & 804014 & 7478826 & 535 & $\operatorname{Sim}(N E)$ & - & - & - \\
\hline :tumitia ${ }^{2}$ & 806036 & 7479911 & 525 & Sim (NE) & 80 & 130) & 47 \\
\hline zenda Ribeirão Claro² & 807271 & 7483403 & 528 & Não & - & - & - \\
\hline aço da Represa ${ }^{2}$ & 787587 & 7482382 & 472 & Não & - & - & - \\
\hline Ita Grande ${ }^{*^{2}}$ & 783460 & 7488200 & 455 & Não & - & - & - \\
\hline to Martins² & 777619 & 7488660 & 453 & $\operatorname{Sim}(N W)$ & - & - & - \\
\hline
\end{tabular}

"Ocorrências não visitadas; (1) Reservatório Tatuí; (2) Reservatório Pirambóia.

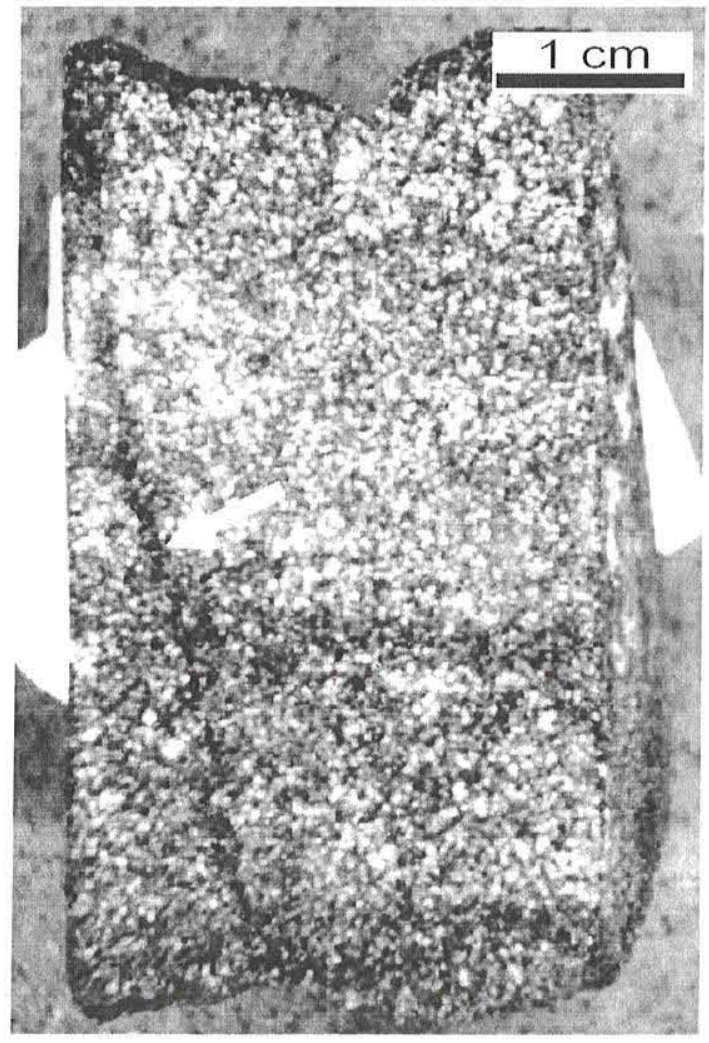

Figura 6 - Amostra de mão de arenito asfáltico, a seta indica fissura preenchida por óleo.

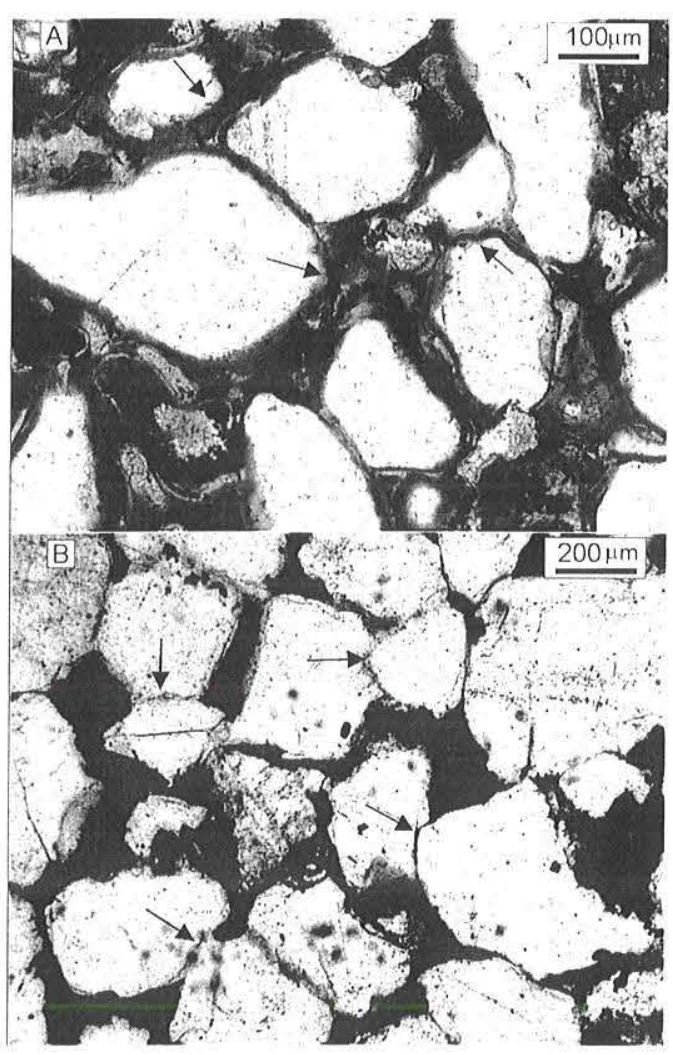

Figura 7 - Tipos de contatos de grãos observados em lâminas delgadas: (A) Ocorrência Sobar; (B) Ocorrência Jacutinga. As setas indicam os contatos entre grãos. 
Betumita, Moquém, Moquém II A ocorrência Betumita localizase no município de Anhembi em um afluente da margem esquerda do Ribeirão dos Pintos, cota 550m. Próximo afloram duas ocorrências menores em área: Moquém e Moquém II (Fig. IA). A ocorrência Betumita é a mais expressiva da área de estudo. Thomaz Filho (1982) apresenta um volume cubado de aproximadamente 5.712.000 barris de óleo pesado, imaturo, de alta viscosidade (aproximadamente $5^{\circ} \mathrm{API}$ ) com médio a al to teor de enxofre ( 2 a $3 \%$ em peso). Em afloramento, verificam-se porções decamétricas de arenitos asfálticos maciços intercalados com arenitos asfálticos listrados que apresentam estratificações cruzadas de porte métrico. Thomaz Filho ( 1982) cita a descoberta de um dique de diabásio não aflorante a partir de campanha de sondagem da Petrobrás na área de ocorrência. $\mathrm{O}$ autor interpreta que o dique agiu como barreira à migração lateral do óleo e como caminho de migração vertical.

As ocorrências Moquém e Moquém II localizam-se no Sítio Moquém, a cerca de $2 \mathrm{~km}$ a oeste da ocorrência Betumita, na cabeceira do córrego Moquém, próximo ao Morro Amarelo, em um afluente de sua margem esquerda. A ocorrência Moquém tem uma espessura aflorante de aproximadamente 5 a $6 \mathrm{~m}$. Sobre a ocorrência há cupinzeiros de cor cinza e textura semelhante ao arenito asfáltico. Em algumas porções da área de ocorrência, há solo avermelhado escuro onde são encontrados clastos de arenito com cimentação ferruginosa. Estes elementos são indícios da presença de rochas básicas em subsuperfície.

Na área das ocorrências Betumita, Moquém e Moquém II ocorrem lineamentos norte-sul interpretados na imagem de sensoriamento remoto e lineamentos aeromagnéticos NW e NE (Fig. 5A). O contato da Formação Teresina com a Formação Pirambóia aflora a aproximadamente $5 \mathrm{~km}$ à oeste da ocorrência (Figs. 1A e 2).

Morro do Bofete, Fazenda São Jorge, Bairro da Mina, Estrada da Mina Estas ocorrências situam-se em uma área de $1.500 .000 \mathrm{~m}^{2}$ no município de Bofete junto ao $\mathrm{Km} \mathrm{173,5}$ da rodovia Castelo Branco, as cotas topográficas variam de 540 até $570 \mathrm{~m}$. Devido à proximidade e distribuição espacial destas ocorrências, supõe-se sua continuidade lateral como um único grande volume impregnado e posteriormente dissecado. Em todas as ocorrências, o betume encontra-se em arenitos da Formação Pirambóia impregnado na fácies eólica com níveis decimétricos de fácies de interduna estéreis. O contato da Formação Pirambóia com a Formação Teresina ocorre a cerca de $100 \mathrm{~m}$ NE da ocorrência da Fazenda São Jorge e está na cota de $540 \mathrm{~m}$.

Na área de afloramento destas ocorrências há presença do sistema linear Torre de Pedra (Fig. IA e Fig. 3). Na área ocorrem lineamentos de direção NS, NE e NW além de diques de rochas básicas. Com base em dados aeromagnetométricos, interpreta-se um alto magnético de direção N50W junto à área (Fig. 5), o qual está relacionado às rochas básicas aflorantes no Morro do Bofete e a possíveis intrusões não aflorantes.

O afloramento do Morro do Bofete tem um nítido padrão de fraturamento (Fig. 8A), também encontrado nas ocorrências do Bairro da Mina. Este fraturamento tem direção principal N3()W, é frequiente a presença de bandas de deformação de direção N1030 E de comprimentos métrico e largura milimétrica. Na Figura 8B observam-se bandas de deformação onde desenvolvem-se fraturas. As bandas de deformação não são preenchidas por óleo, conclui-se que estas estruturas foram geradas em eventos tectônicos pré migração secundária. A direção está relacionada à reativação de estruturas do embasamento. As ocorrências do

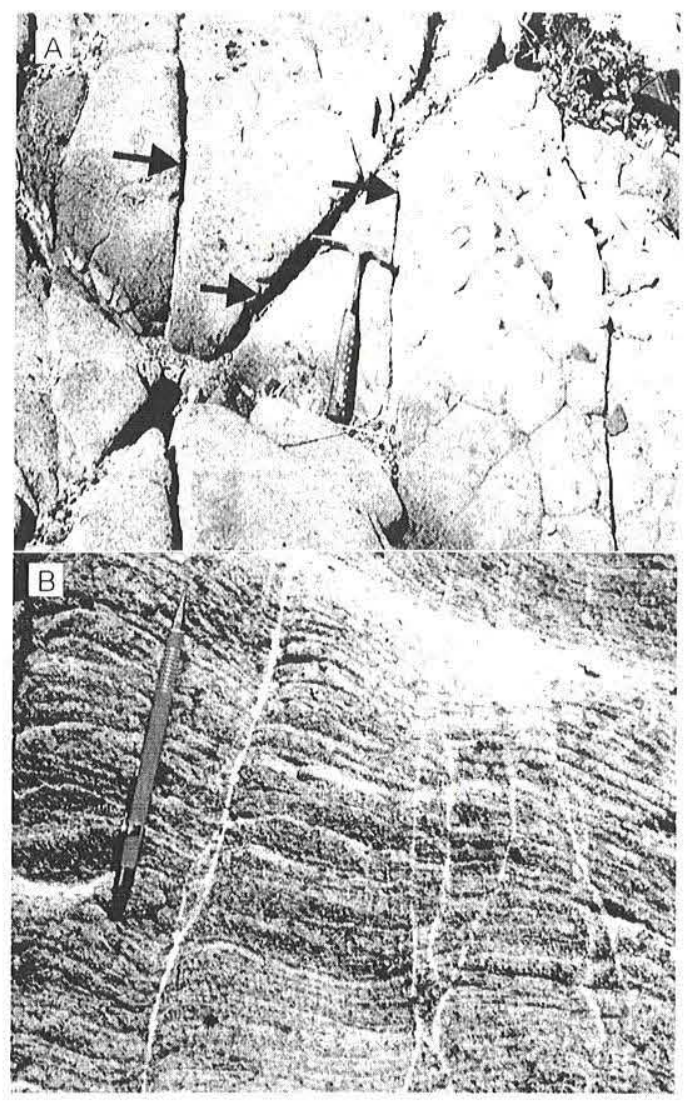

Figura 8 - (A) Detalhe das fraturas na ocorrência do Morro do Bofete, as setas indicam as fraturas; (B) Bandas de deformação não preenchidas por hidrocarbonetos, ocorrência do Morro do Bofete.

Morro do Bofete, Bairro da Mina e Faz. São Jorge estão localizadas em blocos baixos de falhas. Estas falhas têm direções aproximadas NE e NW e foram intrudidas por rochas vulcânicas.

Itatigue ou Guareí I A ocorrência de Itatigue localiza-se no município de Guareí, bairro de Capela Velha, próximo à capela Nossa Senhora Aparecida na cota $710 \mathrm{~m}$. Durante a década de 40 foi explorada pela empresa Itatigue S.A., que produziu gasolina a partir do arenito asfáltico (CNP 1944).

$\mathrm{O}$ arenito asfáltico ocorre na Formação Pirambóia, com granulometria média a grossa, grãos foscos bem arredondados e bem selecionados, com estratificações cruzadas métricas, pouco fraturado e bastante coeso. Na porção superior do afloramento, o arenito asfáltico é homogêneo; na base do afloramento há forte listramento (camadas alternadas com e sem betume). Em campo, notaram-se camadas sem asfalto onde a areia é fina, já nas camadas com asfalto a areia é média a grossa.

A interpretação de imagens de sensoriamento remoto (ETM+ Landsat 7) demonstra a presença de um lineamento de direção NW que passa junto ao vale próximo à ocorrência (Fig. 4A). Podese observar a presença de um expressivo alto magnético ao norte da ocorrência interpretado como um corpo de rocha básica em subsuperfície. Este corpo de dimensões quilométricas é aflorante a aproximadamente $5 \mathrm{~km}$ à nordeste da ocorrência.

Nhaíva ou Itatigue II ou Guareí II A ocorrência de Nhaíva 
localiza-se à noroeste da cidade de Guareí, próximo ao Sítio da Jazida II. A ocorrência está na cota $700 \mathrm{~m}$ em um terreno bastante íngreme, no fundo do vale corre o Ribeirão da Areia Branca.

O betume está em arenitos da Formação Pirambóia com estratificações cruzadas de grande porte. A impregnação irregular de betume causa um aspecto listrado do afloramento na fácies cólicas. Já na fácies de interduna o betume é ausente ou está impregnado nas porções de arenitos médios bem selecionados. Os arenitos asfálticos também apresentam-se com pequenas pintas (centimétricas) não preenchidas, além de canais, geralmente verticais, também não preenchidos. Estas feições foram interpretadas como perturbações pré migração do óleo.

A Formação Teresina aflora $15 \mathrm{~m}$ abaixo da ocorrência, onde o contato da Formação Teresina com a Formação Pirambóia ocorre na cota $685 \mathrm{~m}$. Interpreta-se um lineamento junto à ocorrência, $\mathrm{O}$ qual não foi reconhecido em campo (Fig. 4A). Além disso, interpreta-se uma forte anomalia magnética próxima a ocorrência devido aos corpos básicos aflorantes nas imediações e prováveis corpos em subsuperfície. Junto à ocorrência aflora um dique de rocha básica de atitude N15E/vertical e extensão aflorante de $400 \mathrm{~m}$.

Verificam-se condições geológicas semelhantes entre a ocorrência de Itatigue e a ocorrência Nhaíva. Steveaux et al. (1980) sugerem que esta ocorrência seja um prolongamento lateral da ocorrência ltatigue.

Entre os aspectos condicionantes em ambas ocorrências destacam-se a proximidade de um alto magnético, a proximidade do contato entre as formações Pirambóia e Teresina, a proximidade de lineamentos e o alojamento do betume em fácies eólica.

Sobar ou Carlota Prenz As ocorrências da Fazenda Sobar localizam-se ao norte da cidade de Angatuba, a sudoeste da Represa Capivari, em um afluente da margem esquerda do Rio Capivari chamado Ribeirão do Sargento.

Nesta região aflora o alto estrutural de Carlota Prenz. As três ocorrências estão relacionadas a lineamentos NS localizados no flanco sul da estrutura do Jacu (Figs. 1A e 4A). Um importante lineamento aeromagnético NE corta a área de afloramento dos arenitos asfálticos. Este lineamento está relacionado à Soleira de Angatuba (Fúlfaro 1967).

Em campo, não se pode observar se há continuidade de acumulação entre os pontos dhamados Sobar, Sobar II e III. Nas proximidades da ocorrência Sobar encontra-se o contato entre a Formação Pirambóia e a Formação Teresina na cota 615 m. O arenito asfáltico encontra-se na base da Formação Pirambóia, aproximadamente I () m acima do contato.

Porto Martins, Volta Grande, Braço da Represa A ocorrência de Porto Martins localiza-se às margens da Represa de Barra Bonita, no Rio Tietê. O acesso dá-se pela estrada Botucatu - Santa Maria da Serra. O arenito asfáltico aflora em um barranco da represa, cota $453 \mathrm{~m}$, nas proximidades da vila de Porto Martins. Em função do nível do reservatório, parte do afloramento fica submerso. $\mathrm{O}$ afloramento tem um comprimento de aproximadamente $200 \mathrm{~m}$ e uma espessura aflorante de $8 \mathrm{~m}$. O betume está impregnado em arenitos da Formação Pirambóia com estratificações cruzadas de grande porte, granulometria média a grossa e grãos bem selecionados. A ocorrência de Volta Grande localiza-se também em barranco nas margens da represa de Barra Bonita, acessível somente por via fluvial. A ocorrência do Braço da Represa localiza-se às margens de uma porção assoreada da Represa de Barra Bonita, junto a um córrego.
Jacutinga A ocorrência de Jacutinga localiza-se a sudoeste da cidade de Guareí, próximo a Escola do Bairro do Serrito, a 300 m ao norte da Capela Santa Cruz. O arenito asfáltico aflora na cota 660) $\mathrm{m}$, em um barranco de riacho a aproximadamente $1,5 \mathrm{~m}$ de profundidade.

No topo do afloramento, o betume está impregnado em arenito grosso de seleção boa, grãos subangulosos e aspecto maciço. Este tem espessura de aproximadamente $5 \mathrm{~m}$. Abaixo desta ocorrência encontra-se um arenito asfáltico listrado com $0,3 \mathrm{~m}$ de espessura e grãos de quartzo grossos. Abaixo aflora arenito médio de coloração amarela com níveis síltico argilosos, estéril e com estratificação plano-paralela. Nas amostras de mão foram notadas pequenas fraturas preenchidas por betume. Nesta ocorrência o betume impregna os arenitos da Formação Tatuí.

Na região foram interpretados lineamentos (ETM+ Landsat 7) de direção leste-oeste a aproximadamente $1,5 \mathrm{~km}$ da ocorrência. Também são observados altos magnéticos a aproximadamente 4 km a nordeste e a sul da ocorrência (Fig. 4A). A região da ocorrência tem uma valor intermediário de susceptibilidade magnética e não apresenta anomalias magnéticas.

MAGMATISMOASSOCIADOEGEOCRONOLOGIA Diques básicos ocorrem junto da área de afloramento do arenito betuminoso nas ocorrências do Morro do Bofete, Bairro da Mina, Estrada da Mina, Faz. S. Jorge, Nhaíva, Porto Martins, Betumita e Moquém. Os diques têm largura que não ultrapassa 5 m e são derivados do magmatismo Serra Geral.

A figura 9 apresenta compilação de datações geocronológicas de rochas vulcânicas na Bacia do Paraná próximas à área de estudo. Na região de entorno da área de estudo encontram-se apenas datações pelo método $\mathrm{K} / \mathrm{Ar}$ :

A única datação geocronológica dentro da área de estudo foi feita por Melfi et al. (1967) que obteve a idade K-Ar de $128 \mathrm{Ma}$. Para Rocha-Campos et al.(1988), a fase principal da atividade vulcânica é indicada por resultados radiométricos K-Ar como Cretáceo Inferior (130-135Ma) e a duração do magmatismo (basaltos de derrames e vulcânicas associadas) tem um intervalo sugerido entre 160 e $100 \mathrm{Ma}$.

Renne et al. (1992) apresentam a idade do vulcanismo da Bacia do Paraná com idades ${ }^{40} \mathrm{Ar}^{-39} \mathrm{Ar}$ da ordem de $132.9 \pm(0.6 \mathrm{Ma}$ a 131.4 $\pm 1.6 \mathrm{Ma}$. Para os autores, o magmatismo de toda a província ocorreu em um intervalo aproximado de 1 Ma. Turner et al. (1994) mostram resultados de datações que a bacia do Paraná teve erupções em um período de $10 \mathrm{Ma}$, entre 137 e $127 \mathrm{Ma}$. Stewart et al. (1996), utilizam dados geocronológicos ${ }^{40} \mathrm{Ar}-{ }^{39} \mathrm{Ar}$, complementam a amostragem de Turner et al. (1994), e concluem que a duração total do magmatismo na Bacia do Paraná foi de 10 - $12 \mathrm{Ma}$.

Não há referências com datações ${ }^{40} \mathrm{Ar}{ }^{-39} \mathrm{Ar}$ na área de ocorrência de arenitos asfálticos na Bacia do Paraná em São Paulo. Deste modo, para caracterizar a idade das rochas vulcânicas na área de estudo foram feitas datações geocronológicas pelos métodos K/ $\mathrm{Ar} \mathrm{e}^{40} \mathrm{Ar} /{ }^{39} \mathrm{Ar}$ de quatro localidades diferentes.

As amostras CC1 l y e CC236, cujas datações são de 134_2 Ma ${ }^{40} \mathrm{Ar} /{ }^{39} \mathrm{Ar}$ (rocha total), foram coletadas em um afloramento da soleira de Angatuba (CCl ly) e em um dique de diabásio junto à ocorrência de Porto Martins (CC236). Ao considerarmos o intervalo de duração do magmatismo Serra Geral (Turner et al. 1994, Stewart et al. 1996) estas idades correspondem às primeiras manifestações magmáticas da Ativação Juro-Cretácea e estariam próximas ao pico de erupções em 132 Ma (Stewart et al. 1996). Estas 


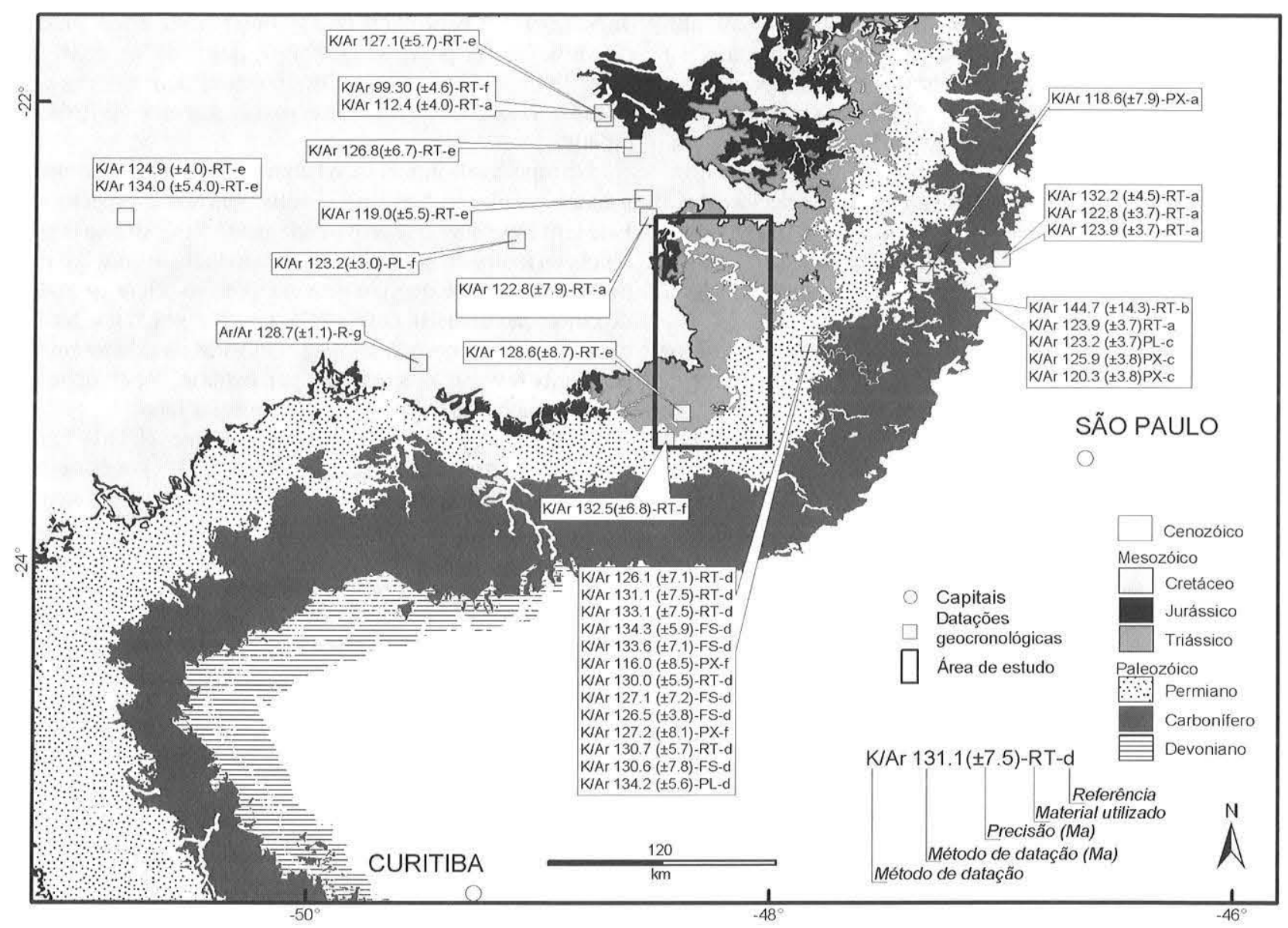

Figura 9- Datações geocronológicas na área de estudo. Referências: (A) Amaral et al. 1966; (B) Creer et al. 1965; (C) McDougal \& Rïegg 1966; (D) Vandoros et al. 1966; (E) Melfi (1967); (F) Centro de Pesquisas Geocronológicas - USP, não publicados. Material: (RT) Rocha total, basaltoldiabásio; (PL) Plagioclásio; (PX) Piroxênio; (FS) Feldspato; (R) Rocha total, riolito.

idades são significativas para a melhor definição tanto do processo de maturação associado às soleiras quanto ao processo de acumulação junto aos diques.

As datações realizadas em afloramentos da porção central da estrutura do Jacu (CC248 e CC252) forneceram idades $\mathrm{K} / \mathrm{Ar}$, em rocha total, da ordem de 129 a $131 \mathrm{Ma}$. Ao considerarmos a idade e o erro máximo da amostra mais jovem de 129 \$3 Ma (CC248) verifica-se que esta faixa de idade recobre o intervalo das datações ${ }^{40} \mathrm{Ar} /{ }^{39} \mathrm{Ar}$. O mesmo ocorre com a amostra CC252 (131 $\left.\pm 4 \mathrm{Ma}\right)$, ou seja, as rochas intrusivas básicas encontradas no centro da Estrutura do Jacu têm aproximadamente a mesma idade dos diques e soleiras associados aos arenitos asfálticos.

Para Yoshida \& Gama Jr: (1982), o basalto/diabásio nunca representou um fator negativo à potencialidade da Bacia do Paraná. Os autores afirmam que a presença de soleiras de diabásio representa um fator positivo de máxima importância à ocorrência de acumulações de hidrocarbonetos. Este fato positivo se concretiza em três sentidos: na geração, como resultado do calor introduzido nas rochas geradoras, favorecendo as reações termoquímicas de transformação de matéria orgânica em hidrocarbonetos; na acumulação, pela presença de fraturas que emprestam ao diabásio características de reservatório; no selamento de estruturas, quan- do o diabásio se apresenta em forma de diques associados a soleiras de diabásio maciço.

POSICIONAMENTOESPACIALEO MAGMATISMO ASSO-

CIADO Foram encontrados diques de rochas básicas aflorantes em parte das ocorrências de arenito asfáltico e fortes anomalias magnéticas, detectadas em levantamento magnetométrico de campo, em todas as ocorrências. Em princípio, esses diques foram associados ao magmatismo Serra Geral. Em comum eles têm a pequena espessura, de ordem métrica, e o posicionamento espacial junto as ocorrências.

Nas ocorrências do Morro do Bofete e Nhaíva, de direção NE, $\mathrm{o}$ arenito asfáltico encontra-se do lado noroeste do dique. Na ocorrência de Porto Martins, encontrou-se um dique com direção $\mathrm{N} 40 \mathrm{~W} /$ vertical. Neste caso, a ocorrência de arenito asfáltico localiza-se na porção suldoeste do dique. Thomaz Filho (1982), com base em dados de sondagem, descreve a ocorrência de um dique de diabásio não aflorante de atitude N20E/vertical, em que a ocorrência de arenito asfáltico está a noroeste.

Segundo Goulart \& Jardim (1982), em toda a Bacia do Paraná, há uma tendência das intrusões se alojarem em áreas de maior espessura de folhelhos, o que pode indicar uma preferência natu- 
ral face aos planos de estratificação destes sedimentos.

No mapa aeromagnético da área (Figs. 4A e B), nota-se a tendência de alinhamento dos altos magnéticos de menor amplitude na direção NW, feição relacionada ao Arco de Ponta Grossa e alinhamentos estruturais como o de Guapiara (Fig. IB), o qual foi estudado por Ferreira (1982).

A associação dos diques com as ocorrências de arenito asfáltico permite elaborar as seguintes hipóteses: (a) a intrusão das soleiras, durante o magmatismo Serra Geral, causou a maturação local da matéria orgânica dos folhelhos Irati (Goulart \& Jardim 1982, Yoshida \& Gama Jr. 1982) e propiciou um caminho de migração secundária junto à parede do dique (Thomaz Filho 1982); e (b), mais precisamente,devido ao posicionamento das ocorrências apenas de um lado dos diques argumenta-se que os diques funcionam como barreiras laterais impermeáveis no caminho de migração dos hidrocarbonetos. A maturação também é explicada pelo magmatismo Serra Geral mas, neste caso, a migração ocorre tardiamente, ou seja, o óleo chega ao reservatório após a consolidação dos diques. De modo geral, considera-se que o mecanismo termal e tectônico da Ativação Juro-Cretácea, na forma de pulsos magmáticos ao longo de aproximadamente $10 \mathrm{Ma}$, propiciou a migração.

É importante observar que, a maioria das ocorrências localizase a oeste dos diques de rochas básicas e próximas aos altos estruturais, preferencialmente com os baixos estruturais à oeste. Interpreta-se que o padrão de migração do óleo foi do centro da bacia para sua borda, os diques NE, no caso, foram as melhores barreiras no caminho de migração. Este padrão de migração provavelmente está relacionado às direções NW predominantes na área e também ao padrão hidrodinâmico da bacia durante a compactação dos pacotes sedimentares e expulsão da água. Além disso, é importante considerar as idades do magmatismo que indicam direção de magmatismo NW-SE, com idades mais antigas na porção centro noroeste da bacia e mais jovens na porção sudeste (Turner et al. 1994, Stewart et al. 1996).

GÊNESE DAS OCORRÊNCIAS Entre os elementos relacionados à gênese do arenito asfáltico, destacam-se o fator de geração relacionado as rochas geradoras do Subgrupo Irati; o fator de acumulação relacionado às rochas reservatório da Formação Pirambóia e secundariamente Formação Tatuí; e finalmente o fator de migração/acumulação que relaciona-se aos caminhos de migração, estruturas acumuladoras e cronologia de eventos. A figura 10 apresenta esquematicamente os principais elementos e processos relacionados à gênese do arenito asfáltico. Cronologicamente apresentam-se os seguintes elementos principais:

1. Geração de zonas de fraqueza, reativação de estruturas e fraturamento da rocha geradora, a partir de atividade tectônica no Permiano e Triássico (Fig. 10-1) evidenciado por estruturas penecontemporâneas como diques clásticos da Formação Teresina, zonas de juntas e falhas;

2. A partir do início do magmatismo (Jurássico Superior Tithoniano) houve aquecimento anômalo da rocha geradora de acordo com a intrusão de soleiras de rocha básica e aumento generalizado do gradiente geotérmico (Fig. 10-2). Este aquecimento propiciou a maturação anômala da matéria orgânica e fraturamento da rocha geradora. Durante estes eventos iniciou-se a migração primária (Fig. 10-3). Provavelmente, nesta época iniciou-se a geração dos altos estruturais como o de Anhembi e Carlota Prenz.

3. A migração secundária e acumulação ocorreram provavel- mente no Cretáceo Inferior (Berriasiano) quando antigas zonas de fraqueza e descontinuidades, geradas durante os primeiros estágios da Ativação Juro-Cretácea, foram utilizadas como condutos. A migração secundária e a acumulação foram afetadas por um
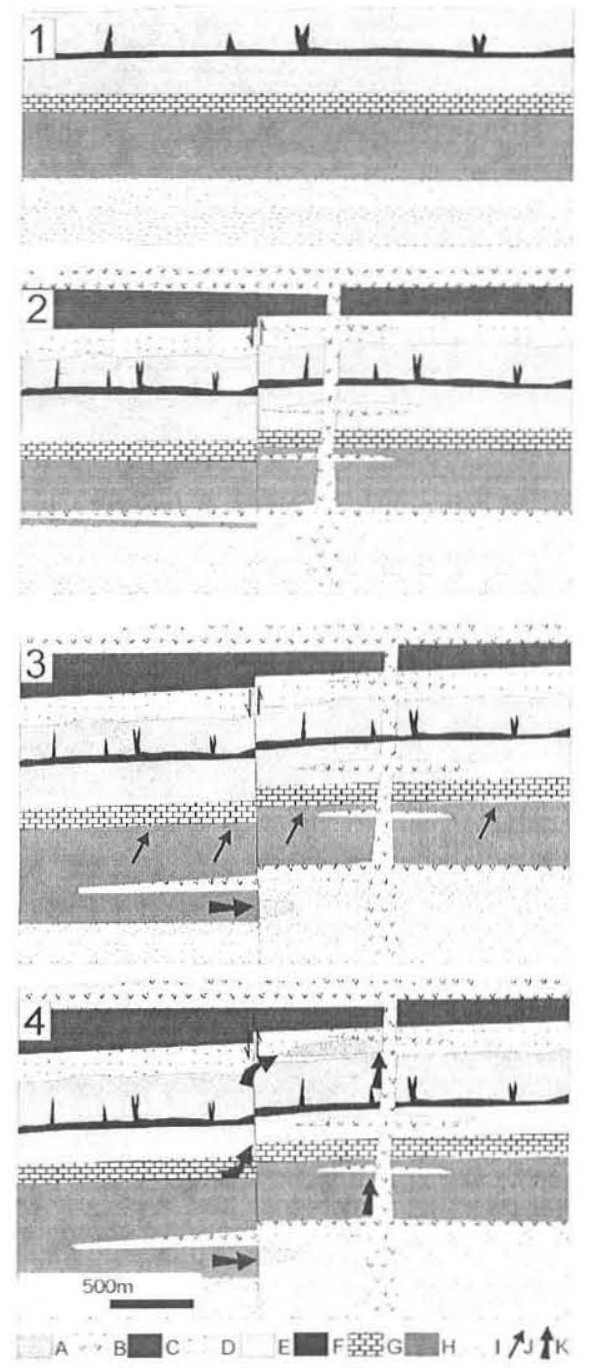

Figura 10 - Modelo de migração: (1) Fraturamento de folhelhos e geração de estruturas penecontemporâneas (sismitos) durante evento tectônico Permiano relacionado à Orogenia La Ventana. (2) Deposição da Formação Pirambóia e Botucatu (TriássicoJurássico). Início da ativação Juro-Cretácea no Jurássico Superior com reativação de estruturas, fraturamento da rocha geradora, início da atividade vulcânica e aquecimento anômalo da rocha geradora (3) Maturação da matéria orgânica e migração primária a partir do aumento anômalo do gradiente geotérmico. (4) Migração secundária ao longo de falhas e diques de rocha básica e camadas permeáveis basculadas. Fluxo em direção aos altos estruturais. Acumulação sob camadas de baixa permeabilidade e junto a paredes de diques.(A) Arenito asfáltico; (B) Formação Serra Geral; (C) Formação Botucatu; (D) Formação Pirambóia; (E) Formação Teresina; $(F)$ Sismitos da Formação Teresina; (G) Formação Assistência; (H) Formação Taquaral; (I) Formação Tatuí (J) Migração primária (K) Migração secundária. 
fator estratigráfico e um fator estrutural. O fator estrutural relaciona-se a uma forte contribuição tectônica, de acordo com o desenvolvimento de altos estruturais, permitindo a migração das regiões de baixo estrutural em direção ao centro dos altos estruturais e geração de caminhos de migração em zonas de falha e limites de blocos tectônicos. O fator estratigráfico diz respeito ao posicionamento da maioria das ocorrências, que estão preferencialmente na porção basal da Formação Pirambóia devido a baixa permeabilidade da fácies de interdunas e fluviais que funcionaram como armadilhas horizontais. Além disso, considera-se que as características de maturidade juvenil e baixa viscosidade dos hidrocarbonetos também contribuiu para o aprisionamento dos hidrocarbonetos. A acumulação ocorreu preferencialmente junto aos diques NE num padrão de fluxo centrífugo em relação às porções mais profundas da bacia e aos baixos estruturais. Infere-se que os caminhos de migração principal estejam relacionados às estruturas de direção NW e que, dessa forma, o fluxo foi preferencialmente interrompido por estruturas selantes NE.

4. A migração ocorreu em direção aos altos estruturais, considera-se que os hidrocarbonetos tenham atingido as rochas reservatório do topo destas estruturas (Fig. 10-4). Estes altos foram posteriormente erodidos em um processo iniciado no final do Cretáceo e que perdura até hoje. As ocorrências encontradas estão em terrenos remanescentes preservados da erosão em porções intermediárias entre os altos e baixos estruturais.

Considera-se que houve contemporaneidade entre os eventos de geração/migração e a acumulação dos hidrocarbonetos dentro de um período de aproximadamente $10 \mathrm{Ma}$, correspondente ao evento tectono-magmático da Ativação Juro-Cretácea. Entretanto, esta contemporaneidade de eventos provavelmente cattsou perda de hidrocarbonetos por falta de sincronismo, ou seja, ocorrência de fluxo de hidrocarbonetos na rocha reservatório sem a geração de estruturas armazenadoras como soleiras de diabásio, por exemplo. Neste caso, nota-se que predominantemente há armazenamento em função das condições de permeabilidade da rocha armazenadora. Nos afloramentos de arenito asfáltico, é possível observar este fato no aspecto listrado e irregular provocado pelo preenchimento do óleo nas estratificações cruzadas de origem eólica. Além disso, todas as ocorrências eram formadas por fácies eólica, não foram encontradas ocorrências associadas aos depósitos fluviais ou fácies de interduna.

Há de se considerar a possibilidade de armadilhas estruturais. Entretanto, segundo Araújo et al. (2000), a contemporaneidade do processo de geração-migração com a fase de formação de trapas estruturais (durante o rifteamento do Gondwana) diminui o potencial das Formações Pirambóia e Botucatu. Baseados nesta premissa, os autores definem que há maior chance de armazenamento nas estruturas originadas no evento Cabo-La Ventana. Entretanto, na área de estudo, as principais estruturas associadas às ocorrências de arenitos asfálticos são os Altos Estruturais de Anhembi, Carlota Prenz, Areia Branca, Quebra e Morro do Bofete originadas principalmente pelos eventos da Ativação Juro-Cretácea.

Conclusões Considera-se que as ocorrências de arenito asfáltico estão diretamente relacionadas a condicionantes estratigráficos e estruturais, mas o processo denudacional é também fundamental para a exposição das ocorrências. O posicionamento estratigráfico das ocorrências conduz à consideração que os arenitos asfálticos são reservatórios exumados. Não há evidências de exudações em rochas Terciárias ou Quaternárias.

Os principais elementos genéticos são o fator estratigráfico e estrutural: as ocorrências estão localizadas nos flancos de altos estruturais e a poucos metros do contato das Fms. Teresina e Pirambóia. A presença de camadas argilosas na base da Formação Pirambóia age como armadilha horizontal e explica o posicionamento estratigráfico das ocorrências. Estas camadas dificultaram a migração vertical de modo que não são encontradas quaisquer ocorrências nos arenitos porosos e permeáveis da Formação Botucatu (Jurássico). Além disso, infere-se que falhas condutoras possibilitaram a migração por dezenas de metros verticalmente e poucos metros lateralmente. A migração lateral ocorreu principalmente ao longo dos planos de estratificação.

O elemento chave na área de estudo é a presença de diques de rochas básicas associados às ocorrências de arenitos asfálticos. O magmatismo agiu nos estágios de geração, migração e acumulação. O magmatismo que gerou as armadilhas verticais (diques) ocorreu principalmente no período inicial da Ativação JuroCretácea, assim como o aumento da temperatura que provocou o início da maturação e geração de óleo imaturo. Já a chegada do óleo no reservatório ocorreu tardiamente durante os estágios finais do magmatismo, quando as armadilhas verticais já estavam consolidadas.

A migração primária ocorreu de acordo com o intenso fraturamento dos folhelhos negros Irati (Araújo et al., 2000). A migração secundária está relacionada com falhas, diques e zonas de juntas gerados em diversos pulsos tectono-magmáticos durante a Ativação Juro-Cretácea. Estruturas mais antigas NE, reativadas a partir do embasamento, são cruzadas por estruturas mais jovens NW. A intersecção destas estruturas forma áreas de dilatação com tensões cisalhantes relativamente pequenas (Gartrell et al. 2003) adequadas para a migração de hidrocarbonetos.

Basculamento de blocos e desenvolvimento de altos e baixos estruturais possibilitaram a aproximação entre rocha geradora e reservatório. A presença de óleo em arenitos da Formação Tatuí é uma evidência do soerguimento da rocha geradora, ou seja, a acumulação na Formação Tatuí encontra-se em um bloco alto.

Conclui-se que a migração do sistema Irati-Pirambóia é caracterizada na área como de alta impedância e drenagem (migração) principalmente vertical. Sistemas petrolíferos de alta impedância (Demaison \& Huizinga, 1994) caracterizam-se por quase todas as acumulações ocorrerem sobre ou próximo a área da rocha geradora, a distância de migração lateral é pequena (geralmente menor que $30 \mathrm{~km}$ ). Além disso, várias acumulações em rochas reservatório de idades diferentes contêm óleo do mesmo tipo genético.

A maior parte das ocorrências associam-se a diques NE, outras a diques NW. A principal diferença entre as ocorrências está relacionada à direção dos diques associados. $\mathrm{A}$ interpretação de lineamentos sugere que os diques NW sejam mais jovens que os de direção NE. Além disso, a estruturação NE do embasamento é uma direção de fraqueza preferencial para a entrada dos primeiros corpos intrusivos. Entretanto, a datação foi obtida apenas em um dique NW (134 2 Ma). As datações dos diques NE não foram bem sucedidas para confirmar definitivamente se o óleo acumulou-se em diques de mesma idade e de direções diferentes. Conclui-se a partir das evidências disponíveis que existe um único modelo genético para todas as ocorrências, com um tempo de migração e acumulação semelhante.

AGRADECIMENTOS À FAPESP pelo apoio financeiro por meio do projeto Auxílio à Pesquisa (Proc. 00/01852-0) e da bolsa de doutorado do primeiro autor (Proc. 99/10417-7). Aos revisores da RBG pelas sugestões ao manuscrito. 


\section{Referências}

Almeida F.F.M. 1967. Origem e evolução da plataforma brasileira. Boletim da Divisão de Geologia e Mineralogia, DNPM, 241:1-36.

Almeida F.F.M. de. 1972. Tectono-magmatic activation of the South American Platform and associated mineralization. In: IUGS, Int. Geol. Congress, 24, Montreal, Proc Section, 3:339-346.

Almeida F.F.M \& Carneiro C.D.R. 1989. The igneous record of the mesozoic activation of South American Platform. Geotectonica et Metallogenia, 13:308-325.

Amaral A., Cordani U., Kawashita K., Reynolds J.H. 1966. Potassiumargon dating of basaltic rocks from southern Brazil. Geoch. Cosm. Acta, 30: 159-189.

Andrade S.M., Soares P.C. 1971. Geologia de Semi-detalhe no centro leste de São Paulo. Rio de Janeiro, Petrobrás, DESUL relatório 407, $52 \mathrm{p}$.

Araújo L.M.. Triguis J.A., Cerqueira J.R., Freitas L.C. da S. 2000. The atypical Permian Petroleum System of the Paraná Basin, Brazil. In M.R. Mello \& B.J. Katz (eds.) Petroleum systems of South Atlantic margins. AAPG Memoir 73:377-402.

Briguetti J.M.P. 1994. Faciologia dos sedimentos da Formação Pirambóia na região de Rio Claro (SP). Instituto de Geociências e Ciências Exatas, UNESP, Rio Claro, Dissertação de Mestrado, 124 p.

Caetano-Chang, M.R. 1997. A Formação Pirambóia no Centro-Leste do Estado de São Paulo. Instituto de Geociências e Ciências Exatas, UNESP, Rio Claro, Livre-Docência, 196 p.

CNP. 1944. Relatório de 1944. Rio de Janeiro, Conselho Nacional do Petróleo, $280 \mathrm{p}$

Collon A. 1897. Le petrole dans les environs du Mont de Bofete et de Porto Martins, dans l'Etat de São Paulo. São Paulo, Instituto Geográfico e Geológico, Secretaria de Agricultura do Estado de São Paulo, $69 \mathrm{p}$.

CPRM - Companhia de Pesquisa de Recursos Minerais. 200) la. Mapa Geológico do Brasil. Rio de Janeiro. (Escala 1:2.500.000). CDROM.

CPRM - Companhia de Pesquisa de Recursos Minerais. 2001b. Mapa Tectônico do Brasil. Rio de Janeiro. (Escala 1:2.500.000). CD-ROM.

Creer K.M., Miller J.A. \& Smith G. 1965. Radiometric age of the Serra Geral Formation. Nature, 207:282-283.

DAEE-UNESP. 1984. Landim, P.M.B. (coordenador), Mapa Geológico do Estado de São Paulo, escala 1:250.000 - Folha Botucatu.

Demaisom G., Huizinga B.L. 1994. Genetic classification of petroleum systems using three factors: charge, migration, and entrapment. In: Magoon, L.B. and W.G. Dow (eds.), 1994, The petroleum system - from source to trap: AAPG Memoir 60.

Ferreira F.F.J. 1982. Integração de dados aeromagnéticos e geológicos:configuração e evolução tectônica do Arco de Ponta Grossart. Inst. de Geociências. Universidade de São Paulo. São Paulo, Dissertação de Mestrado, 169 p.

Franzinelli E. 1972. Arenitos asfálticos do estado de São Paulo. Inst. de Geociências. Universidade de São Paulo, São Paulo, Tese de Doutoramento, $104 \mathrm{p}$.

Fúlfaro, V.J. 1967. Contribuiçãoo à geologia da região de Angatuba, Estado de São Paulo. Instituto de Geociências, Universidade de São Paulo, São Paulo, Tese de Doutoramento, 91 p.
Fúlfaro V. J., Saad A. R., Santos M. V., Vianna R. B. 1982. Compartimentação e evolução tectônica da Bacia do Paraná. Rev. Bras. Geoc.,12:590-611.

Fúlfaro V.J., Saad. A.R., Perinotto J.A.J., Etchebehere M.L.C. 1997. Paraná Basin: Mineral Resource Potentials in Brazil, Uruguay, and Paraguay. Intern. Geol; Rv., 39:703-722.

Matos S.L.F. 1995. O contato entre o Grupo Passa Dois e a Formação Pirambóia na borda leste da Bacia do Paraná no Estado de São Paulo São Paulo. Inst. de Geociências, Universidade de São Paulo, São Paulo, Dissertação de Mestrado, 110 p.

McDougall I. \& Rüegg N.R. 1966. Potassium-argon dates on the Serra Geral Formation of South America. Geoch. Cosm. Acta, 30:191195.

Gartrell A., Zhang Y., Lisk M., Dewhurst D. 2003. Enhanced hydrocarbon leakage at fault intersections: an example from the Timor Sea. Northwest Shelf, Autralia. J. Geochem. Explor:, 79:361-365.

Goulart E.P. \& Jardim N.S. 1982. Avaliação geoquímica das formações Ponta Grossa e Irati - Bacia do Paraná. In: Geologia da Bacia do Paraná - Reavaliaşão da Potencialidade e Prospectividade em Hidrocarbonetos. São Paulo, Paulipetro/CESP/IPT, p. 4I - 74.

Melfi A. 1967. Potassium-argon ages for core samples of basaltic rocks from Southern Brazil. Geoch. Cosmoch. Acta.31:1079-1089.

Oliveira E.P. 1920. Rochas petrolíferas do Brasil. Rio de Janeiro, Serviço Geológico e Mineralógico do Brasil, p.101-102.

Oliveira E.P. 1940. História da pesquisa de petróleo no Brasil. Rio de Janeiro, Serviço de publicidade agrícola, 208p.

Renne P. R., Ernesto M., Pacca I.G., Coe R.S., Glen J.M., Prévot M., Perrin M. 1992. The age of Paraná Flood Volcanism, Rifting of Gondwanaland, and the Jurassic-Cretaceous Boundary. Science, 258: $975-979$.

Rocha-Campos A.C., Cordani U.G., Kawashita K., Sonoki H.M., Sonoki I.K. 1988. Age of Paraná Flood Vulcanism. In: E.M. Picirillo \& A. Melphi (eds). The Mesozoic flood basalts of the Parana Basin: petrogenetic and geophysical aspects. São Paulo, IAC/USP, 600 p.

Riccomini C. 1995. Tectonismo gerador e deformador dos depósitos sedimentares pós-gondvânicos da porção centro-oriental do estado de São Paulo e áreas vizinhas. Instituto de Geociências, Universidade de São Paulo, São Paulo, Livre-docência, 100 p.

Schobbenhaus, C.; Campos, D.A.; Derze, G.R.; Asmus, H.E. 1984. Geologia do Brasil. Texto explicativo do Mapa Geológico do Brasil (escala $=1: 2.500 .000)$, DNPM, $501 \mathrm{p}$.

Simoneit B.R.T., Brenner S., Peters K.E., Kaplan I.R. 1978a. Thermal alteration of Cretaceous black shale by basaltic intrusions in the eastern Atlantic. Nature, 273:501-504.

Simoneit B.R.T., Brenner S., Peters K.E., Kaplan I.R. 1978b. Thermal alteration of Cretaceous black shale by basaltic intrusions in the eastern Allantic - II. Effects on bitumen and kerogen. Geoch. Comoch. Acta, 45:1581-1602.

Soares P.C., 1971. Elementos estruturais da parte nordeste da Bacia do Paraná: classificação e gênese. In: SBG, Congr. Bras. Geol., 28, Porto Alegre, Anais, 1:107 - 121.

Soares P.C. 1973. O Mezosóico Gonduânico no Estado de São Paulo. Departamento de Geologia e Mineralogia da Faculdade de Filosofia, Ciências e Letras de Rio Claro, Rio Claro, Tese de Doutoramento, 
$1.52 \mathrm{p}$.

Steveaux J.C., Santos M.V., Seignemartin C.L. 1980. Geologia do bloco 49, balizado pelas cidades de Avaré, Itapeva e Itapetininga. São Paulo, Paulipetro CESP/IPT, 90p. (Relatório BP-016/80)

Stewart K., Turner S., Kelley S., Hawkesworth C., Kirstein L., Mantovani M. 1996. 3-D, ${ }^{40} \mathrm{Ar}^{{ }^{30}} \mathrm{Ar}$ geochronology in the Paraná continental flood basalt province. Earth Planet. Sci. Lett., 143:95-109.

Thomaz Filho A. 1982. Ocorrência de arenito betuminoso em Anhembi (SP) - cubagem e condicionamento geológico. In: SBG, Congr: Bras.Geol., 32, Salvador, Ancis, 5:2344-2348.

Turner S., Regelous M., Kelley S., Hawkesworth C., Mantovani M. 1994. Magmatism and continental break-up in the South Atlantic: high precision ${ }^{40} \mathrm{Ar}-{ }^{39} \mathrm{Ar}$ geochronology. Earth Planet. Sci. Lett., 121:333-348.

Vandoros P., Rüegg N.R. \& Cordani U.G. 1966. On potassium-argon age measurements of basaltic rocks from southern Brazil. Earth Plan.
Sci. Letters, 1:449-452.

Washburne C.W. 1930. Geologia do Petróleo do Estado de São Paulo. Rio de Janeiro, Departamento Nacional de Produção Mineral, Ministério de Agricultura, 228 p.

Yoshida R. \& Gama JR. E. 1982. Geologia da Bacia do Paraná: reavaliação da potencialidade e prospectividade em hidrocarbonetos. In: Geologia da Bacia do Paraná - Reavaliação da Potencialidade e Prospectividade em Hidrocarbonetos. São Paulo, Paulipetro/CESP/ IPT, p. 1 - 17.

Zalán P.V., Wolff S., Conceição J.C.J., Astolfi M.A.M., Vieira I.S., Appi V.T., Zanotto A., Marques A. 1991. Tectonics and sedimentation of the Paraná Basin. In: Gondwana Seven Proceedings. São Paulo, Instituto de Geociências - USP, p. 83-117.

Manuscrito A-1388

Recebido em 14 de novembro de 2002

Revisão dos autores em 10 de abril de 2004

Revisão aceita em 20 de abril de 2004 